\title{
EFFECTS OF pH, DOSAGE AND CONTACT TIME ON BORON REMOVAL FROM SYNTHETIC SALINE WATER USING Moringa oleifera SEEDS
}

\author{
MOHAMmed SaEdi JAMi ${ }^{1 *}$, NUR SYahirah Zakaria ${ }^{1}$, MOUSSa MaHaMed \\ Ahmed $^{1}$, Nik Rashida Nik Abdul Ghani ${ }^{1}$, Mohammed NGabura ${ }^{2}$, \\ AND MANi MALAM AHMAD ${ }^{3}$ \\ ${ }^{I}$ Department of Biotechnology Engineering, Kulliyyah of Engineering, \\ International Islamic University. Malaysia, Jalan Gombak, \\ 53100 Kuala Lumpur, Malaysia \\ ${ }^{2}$ Department of Chemical and Environmental Engineering, Faculty of Engineering, \\ Universiti Putra Malaysia, 43400 UPM Serdang, Selangor, Malaysia \\ ${ }^{3}$ Department of Biology, Faculty of Science, Kano University of Science and Technology, \\ Wudil, 3244 Wudil-Gaya Road, Kano, Nigeria \\ *Corresponding author: saedi@iium.edu.my
}

(Received: $18^{\text {th }}$ July 2019; Accepted: $12^{\text {th }}$ May 2020; Published on-line: $4^{\text {th }}$ July 2020)

\begin{abstract}
Boron is one of the key elements required in flora, fauna, as well as human beings. However, human life and eco-systems could be seriously affected when exposed to excessive levels of boron, especially in seawater and groundwater. In this work Moringa oleifera was selected as a precursor adsorbent owing to its eco-friendliness characteristics and favourable removal efficiency of adsorbates. Besides, M. oleifera does not significantly affect the conductivity of water and $\mathrm{pH}$ value after the treatment. The main aim of this work was to investigate the potentiality of $M$. oleifera in the treatment of boron from contaminated saline water. The effect of adsorption parameters such as $\mathrm{pH}(7-9)$, adsorbent dose of $4000-8000 \mathrm{mg} / \mathrm{L}$ of solution and contact time of $60-180 \mathrm{~min}$ was thoroughly investigated. Face-centred Central Composite Design (FCCCD) was applied to optimize these parameters. Consequently, the highest percentage of removal $(65 \%)$ was achieved at the $\mathrm{pH}$ of $8,120 \mathrm{~min}$ of contact time and $6000 \mathrm{mg} / \mathrm{L}$ of adsorbent dosage. The adsorption studies stated that the adsorption fitted well with the Freundlich isotherm. Therefore, the outcome of this work revealed that boron could be significantly treated using a prepared adsorbent from M. oleifera.
\end{abstract}

ABSTRAK: Boron merupakan salah satu elemen yang diperlukan oleh flora, fauna, juga manusia. Walau bagaimanapun, hidup manusia dan ekosistem pasti terkesan apabila di dedahkan secara berlebihan, terutama pada air di lautan dan daratan. Kajian ini menggunakan Moringa oleifera sebagai penjerap kerana ia mempunyai ciri-ciri mesra dan berkesan membuang bahan terjerap dengan berkesan. Selain itu, M. oleifera tidak langsung memberi kesan kepada konduktiviti air dan nilai $\mathrm{pH}$ selepas perawatan. Tujuan utama kajian ini adalah mengkaji potensi $M$. oleifera dalam larutan rawatan air garam boron yang tercemar. Kesan parameter penjerapan seperti $\mathrm{pH}$ (7-9), dos penjerapan 4000 - 8000 mg/L larutan dan masa interaksi 60 - 180 minit di kaji dengan teliti. Kaedah Komposisi Tumpuan Tengah Muka (FCCCD) digunakan bagi mengoptimumkan parameter-parameter ini. Hasilnya, peratus tertinggi penyingkiran adalah sebanyak $(65 \%)$ pada $\mathrm{pH}$ 8, 120 min masa interaksi dan $6000 \mathrm{mg} / \mathrm{L}$ dos penjerapan. Kesimpulannya, kajian penjerapan ini menyokong kuat teori isoterma Freundlich. Oleh itu, hasil kajian ini menunjukkan boron dapat dirawat dengan menggunakan larutan penjerapan daripada $M$. oleifera. 
KEYWORDS: optimization; boron; sea water; Moringa oleifera seeds

\section{INTRODUCTION}

Boron is a major constituent needed in plants, animals, and humans for metabolic and biosynthesis $[1,2]$. It is an essential component for carbohydrate metabolism, sugar translocation, and other hormonal mechanisms in plants. It was reported that it is the basic marker for animal and human immune mechanism specifically in bone metabolism and central nervous systems [3]. Its deficiency in plants leads to retarded growth and enzymatic activities that could result in the death of the plants. In human and animals, deficiency may lead to low absorption capability for nutrient components and cause the deformity in embryo development for vertebrates as well as in cardiovascular coronary [4]. However, despite the importance of this chemical to plant and animal life, its redundancy (excess) may be toxic, leading to severe health and environmental damages. The toxicity in humans is manifested by nausea, vomiting, poor appetite, and weight loss [5, 6]. Moreover, its excess in soil and irrigation water could endanger plant life [7].

Numerous conventional techniques for boron removal from sea water are reported including reverse osmosis (RO), membrane distillation, and ion exchange methods [8-10]. However, these current techniques are identified with certain drawbacks such as high cost and high energy intensity [11]. Adsorption technique is an effective and recommended method to remove boron from water even at very low concentration. A wide range of sorbents have been used in the adsorption processes to remove boron such as activated carbon, clays, fly ash, biological materials, natural minerals, nanoparticles, layered double hydroxide, and other complexing membranes [12-14]. On the other hand, adsorption technique using agro-based materials was found to be cost effective, eco-friendly, easily accessible, easy to handle, and highly selective [15].

Moringa oleifera trees also known as a drumstick trees have a deciduous shrub characteristic in a rapidly growing small tree. The size of the tree is about $10-13 \mathrm{~m}$ tall and $35-45 \mathrm{~cm}$ in diameter with an umbrella-shaped open cap [16]. Moringa oleifera belongs to the Moringaceae family and is the most widely distributed species worldwide $[17,18]$. The fruit changes to brown colour when mature and usually contains about 10 to 50 seeds inside it [16]. The Moringa oleifera seeds have demonstrated to be persuasive as primary coagulants for water treatment after being tested over the years and can be compared to conventional chemical coagulant (alum). Its high efficiency removal rate and its edible properties make the $M$. oleifera seeds adsorbent a standout potential candidate for Boron removal from sea water [19].

In the present study, the optimal values of $\mathrm{pH}$, contact time and adsorbent dosage as the process parameters for effective boron removal were established using face-centred central composite design (FCCCD). In addition, the prediction ability of the established model was tested based on the Freundlich and Langmuir adsorption isotherms.

\section{MATERIALS AND METHODS}

\subsection{Materials}

The dry Moringa oleifera seeds were purchased from an accredited agent in Sabah, Malaysia. All reagents were commercial products of analytical grade. 


\subsection{Experimental Procedures}

\subsubsection{Sample Preparation}

The seeds of Moringa oleifera were peeled manually and dried in the oven at a temperature of $105{ }^{\circ} \mathrm{C}$ for 24 hours to eliminate the moisture content according to the reported standard procedure [20]. Afterwards, the seeds were ground in a common processor and then sieved using standard sieve of $212 \mu \mathrm{m}$ size mesh. Stock solution for synthetic sea water was prepared by measuring and suspending $5.719 \mathrm{~g}$ of boric acid into $1000 \mathrm{~mL}$ distilled water from which a working concentration of $5 \mathrm{mg} / \mathrm{L}$ was made through an appropriate dilution. For synthetic seawater preparation, stock solution of boron (1000 $\mu \mathrm{g} / \mathrm{mL}$ ) was prepared by dissolving $0.5636 \mathrm{~g}$ boric acid in water and diluting to $100 \mathrm{~mL}$ in a volumetric flask as described by Zarei et al. [21].

\subsubsection{Spectrophotometric Assay}

For the analysis of Boron depletion, samples were systematically withdrawn according to the methods described by Zarei et al. and Ahmad et al. [21, 22]. Standard methylene blue method by Zarei et al. [10] was applied and the analysis was done by observing the absorbance on spectrophotometer. One (1) $\mathrm{mL}$ of the boron solution was poured into $15 \mathrm{~mL}$ centrifuge tube then $0.5 \%$ of $\mathrm{NaF}(1 \mathrm{~mL})$ was added followed by $1 \mathrm{~mL}$ of $1.5 \mathrm{mM}$ methylene blue and $1 \mathrm{~mL}$ of $0.2 \mathrm{M}$ sulfuric acid. Then, the contents were mixed well by vortex before diluted with $1 \mathrm{~mL}$ distilled water. Dichloromethane $(100 \mu \mathrm{L})$ was prepared in $400 \mu \mathrm{L}$ of acetonitrile solvent and added into the reaction solution. After a cloudy solution was formed, the solution was centrifuged for 2 minutes at $3800 \mathrm{rpm}$. The supernatant was discarded and the remaining pellet was dissolved with $400 \mu \mathrm{L}$ acetonitrile. Then, the absorbance was measured at $657 \mathrm{~nm}$. The standard curve (Fig. 1) from this assay was utilized to determine the final concentration of boron.

\subsubsection{Batch Adsorption Experiments}

A series of experiments was conducted batch wise in $500 \mathrm{~mL}$ Erlenmeyer flasks mounted on a hot plate with magnetic stirrer. The flask was covered with aluminium foil paper to prevent splash. The agitation was maintained at $200 \mathrm{rpm}$, while ambient temperature was adopted throughout the experiment. The removal efficiency of boron (\%) was determined using the Eq. 1:

$$
\text { Boron removal }(\%)=\frac{\left(C_{i}-C_{f}\right)}{C_{i}} \times 100
$$

where $C_{\mathrm{o}}$ and $C_{\mathrm{t}}$ are the initial and final concentrations of lead in the solution $(\mathrm{mg} / \mathrm{L})$, respectively.

\subsubsection{Adsorption isotherm}

Langmuir and Freundlich isotherms were investigated to explain the metal ion distribution between solid and liquid phases. The Langmuir model demonstrates there is no interaction between adsorbate molecules on adjacent sites and the adsorption occurs on a set of distinct localized adsorption sites within the natural material [23], whereas the Freundlich theory states that the uptake of metal ions occurs on a heterogeneous surface by monolayer sites adsorption. The adsorption capacity of the $M$. oleifera can be obtained from Eq. 2 below.

$$
Q=\frac{\left(C_{i}-C_{f}\right) V}{m}
$$


where $C_{\mathrm{i}}$ is the initial concentration $(\mathrm{mg} / \mathrm{L})$ and $C_{\mathrm{f}}$ is the final concentration $(\mathrm{mg} / \mathrm{L})$. The standard and linearized equations for Langmuir isotherm are given in Eq. 3 and Eq. 4:

$$
\begin{aligned}
& q_{e}=\frac{\theta b C_{e}}{1+b C_{e}} \\
& \frac{C_{e}}{q_{e}}=\frac{1}{b q_{m}}+\frac{C_{e}}{q_{m}}
\end{aligned}
$$

where, $q_{\mathrm{e}}$ is the quantity of adsorbate adsorbed in $\mathrm{mg} / \mathrm{g}, C_{\mathrm{e}}$ is the equilibrium concentration $(\mathrm{mg} / \mathrm{L}), b$ is the constant of adsorption equilibrium $(\mathrm{L} / \mathrm{mg})$ which is related to the energy of adsorption, and $q_{\mathrm{m}}(\mathrm{mg} / \mathrm{g})$ is the maximum adsorption capacity. The Langmuir isotherm experimental data were plotted as $C_{\mathrm{e}} / q_{\mathrm{e}}$ against $C_{\mathrm{e}}$ graph. The model parameters can be obtained from the slope of the straight-line graph, $1 / q_{\mathrm{m}}$ and the $y$-intercept, $1 / b q_{\mathrm{m}} 1 / b[24]$.

The Freundlich isotherm equations can be expressed as given in Eq. 5:

$$
q_{e}=K C_{e}^{1 / n}
$$

Linearized form of Eq. 5 is given as:

$$
q_{e}=K C_{e}^{1 / n}
$$

where $K_{F}\left(\mathrm{~mol}^{2} / \mathrm{KJ}^{2}\right)$ is an indicator of adsorption capacity and $1 / n(\mathrm{mg} / \mathrm{L})$ is a measure of intensity of adsorption. In Freundlich isotherm, the linearized graph of $\log \left(q_{\mathrm{e}}\right)$ against $\log$ $\left(C_{\mathrm{e}}\right)$ gives a slope of $1 / n$ and an intercept of $\log 10(K)$.

\subsection{Design of Experiment and Statistical Analysis}

Three process parameters, namely, $\mathrm{pH}$ (7-9), contact time (60-180 min) and adsorbent dosage (0.4-0.8 g) were optimized using FCCCD with Design Expert software (Stat-Ease, Inc., Version 10.0.5.0 Minneapolis, USA) as reported by [24]. A total of 20 experiments with three-coded levels $(1,0$ and +1$)$ were conducted. Regression analysis was performed using second-order polynomial empirical model to correlate the influence of independent variables on boron removal (Eq. 7).

$$
Y=\beta_{0}=\sum_{i} \beta_{i} x_{i}+\sum_{i i} \beta_{i i} x_{i}^{2}+\sum_{i j} \beta_{i j} x_{i} x_{j}
$$

where $Y$ is the predicted response, $\beta_{o}$ is the offset term, $\beta_{\mathrm{i}}$ is the $\mathrm{i}^{\mathrm{th}}$ linear coefficient, $\beta_{\mathrm{ii}}$ is the $\mathrm{i}^{\text {th }}$ quadratic coefficient, and $\beta_{\mathrm{ij}}$ is the $\mathrm{ij}{ }^{\text {th }}$ interaction coefficient.

\section{RESULTS AND DISCUSSION}

\subsection{Standard Curve of Boron}

The standard curve used in finding the final concentration of boron illustrated in Fig. 1. The equation was $y=0.0054 x+0.0363$, where $R^{2}=0.9702$. The standard curve is accepted as the value of $\mathrm{R}^{2}$ was more than 0.95 . The final concentration of boron determined by inserting the measured value of absorbance at $657 \mathrm{~nm}$ of solution after the batch experiment was done as $y$ value whereby the $x$ value is the final concentration of boron. 


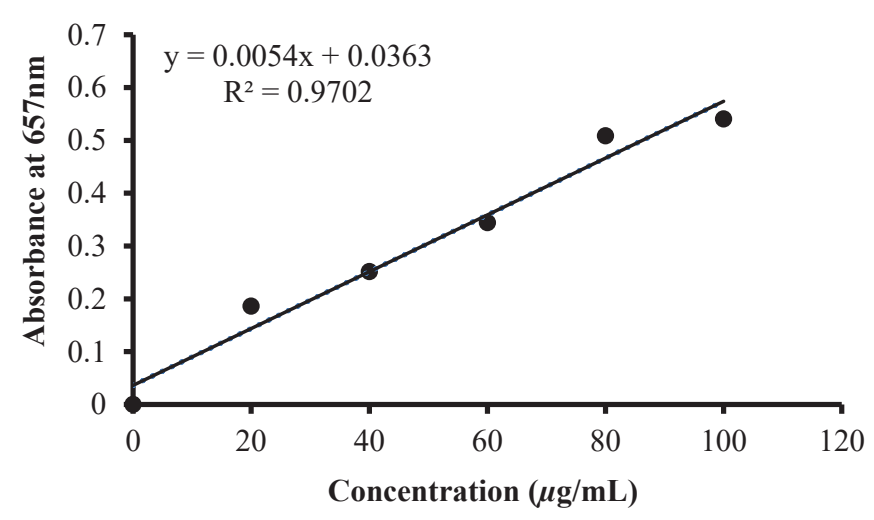

Fig. 1: Standard curve of boron.

\subsection{Effect of Time}

Figure 2 shows the effect of contact time for the adsorption of boron using Moringa oleifera seeds. The figure shows that the contact time has remarkable influence on the adsorption of boron. The highest boron removal by M. oleifera seeds can be observed at 120 minutes of contact time with $60 \%$ of removal.

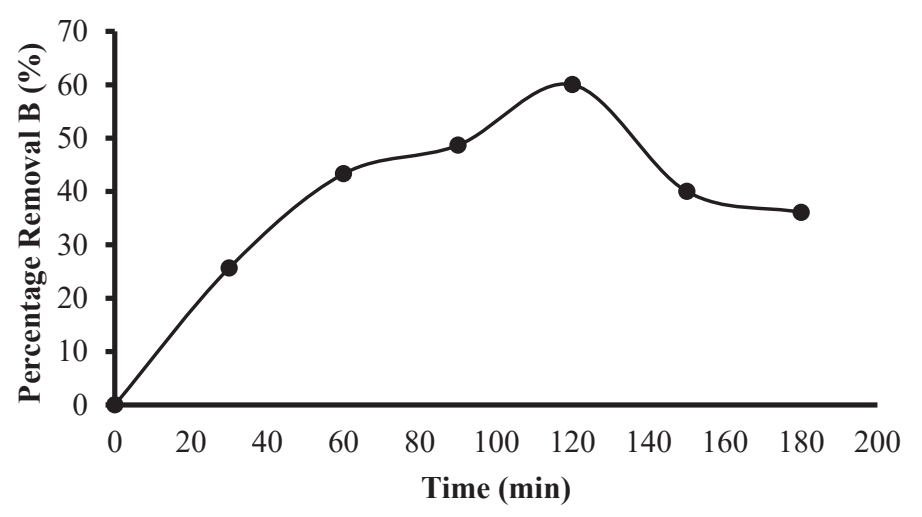

Fig. 2: Effect of time on boron removal at $\mathrm{pH} 8$ and $6000 \mathrm{mg} / \mathrm{L}$ of adsorbent dosage.

Initially, the percentage removal of boron increased gradually until it reached the peak that is 120 minutes of contact time, afterwards, the rate starts decreasing until equilibrium was achieved. This trend could be due to the saturation on the available adsorption sites present on the $M$. oleifera seed. Initially the adsorption is fast but gradually decreased after it reached equilibrium due to the aggregation of M. oleifera seeds when it is increased. This phenomenon decreased the availability of adsorption surface area and increased the diffusion path length of boron. Besides, the unavailability of the surface area of adsorbent, the number of vacant sites and the interaction between the ions in the solution would lower the adsorption process $[25,26]$.

\subsection{Effect of pH}

The percentage of boron removal was observed to be at its highest peak in the condition of $0.6 \mathrm{~g}$ adsorbent dosage within 120 minutes of contact time. The agitation speed was fixed at $200 \mathrm{rpm}$ throughout the experiment. The adsorption capacity of the adsorbent with varying $\mathrm{pH}$ values was plotted in Fig. 3. 


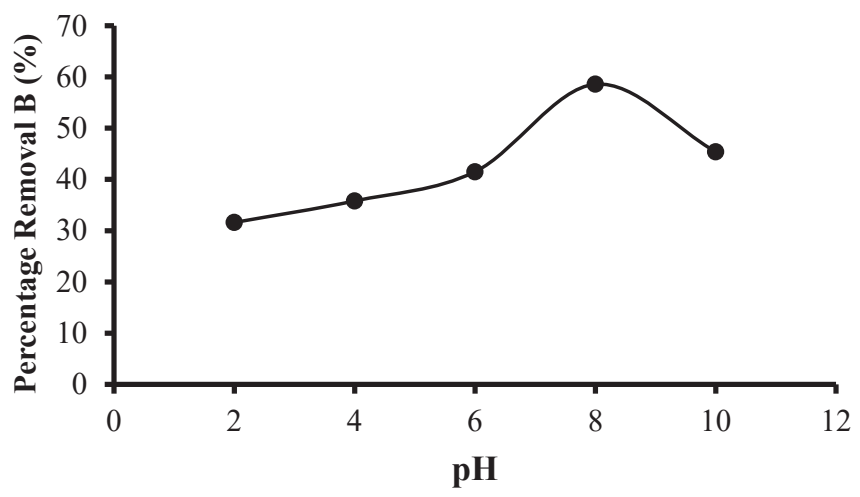

Fig. 3: Effect of $\mathrm{pH}$ on boron removal at 120 minutes of contact time and adsorbent dosage of $6000 \mathrm{mg} / \mathrm{L}$.

The effect of $\mathrm{pH}$ on the adsorption of boron onto Moringa oleifera seed was studied in the range from $\mathrm{pH} 2$ to $\mathrm{pH} 10$. The result displayed that boron removal was at its highest peak at $\mathrm{pH} 8$ with about 59\% removal of boron. Initially, the percentage removal of boron increased with an increment of $\mathrm{pH}$ until it reached optimal $\mathrm{pH}$ value of 8 . Further $\mathrm{pH}$ increment causes a dramatic decline in the adsorption percentage because of the electrostatic force of attraction become weak between the different charges of an adsorbate and adsorbent resulting in the lowering of adsorption. Simply at that $\mathrm{pH}$, the protein of $M$. oleifera seeds have isoelectric point where over $90 \%$ of the amino acid molecules are in ionized state [21].

\subsection{Effect of Adsorbent Dosage}

The effect of adsorbent dosage on boron removal was investigated at varying adsorbent dosage from 2000-10000 mg/L of boron solution with $5 \mathrm{mg} / \mathrm{L}$ of boron concentration. The results are presented in Fig. 4.

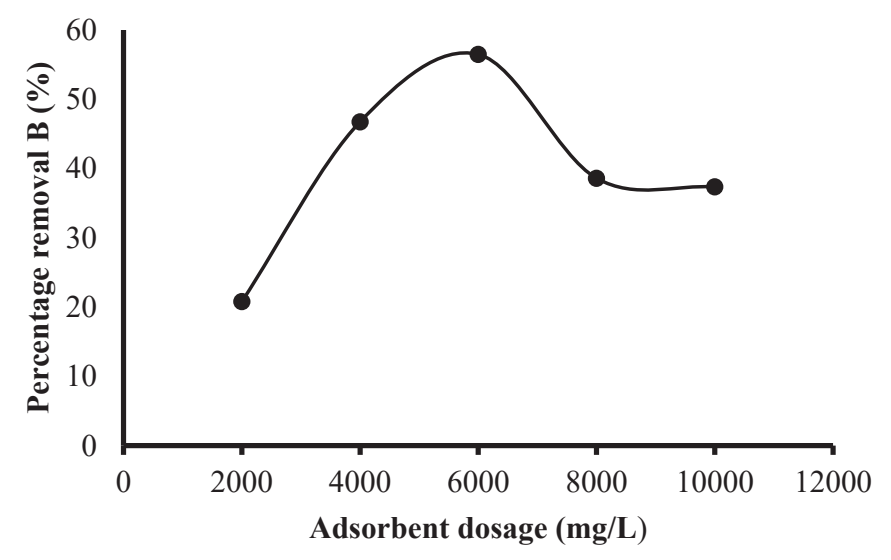

Fig. 4: Effect of adsorbent dosage on boron removal at 120 minutes of contact time with $\mathrm{pH} 8$.

From Fig. 4 above, the graph displayed that the highest percentage removal of boron using Moringa oleifera seeds was at $6000 \mathrm{mg} / \mathrm{L}$ of adsorbent dosage. The removal of boron increases rapidly from $2000 \mathrm{mg} / \mathrm{L}$ until it reached maximum peak at $6000 \mathrm{mg} / \mathrm{L}$ adsorbent dosage before gradually decreases and approaching equilibrium at $10000 \mathrm{mg} / \mathrm{L}$ dosage. Continuous increase of dosage does not increase the boron removal percentage because the effective contact surface area of the adsorbent decreased at higher adsorbent dosage which 
results in a decreasing of unit adsorption capacity as too large amount of adsorbent will reduce the adsorption saturation sites besides create particle aggregates which cause a decrease in the total surface area that results in a decrease of adsorption capacity.

\subsection{Adsorption Isotherm}

The distribution of metal ions between liquid phase and the solid phase can be described by several isotherm models such as Langmuir and Freundlich [23]. The equilibrium data for Freundlich and Langmuir isotherm models were presented in Table 1 and 2, respectively while the linearized graph of the two Freundlich and Langmuir models was plotted as shown in Fig. 5 and Fig. 6, respectively.

Table 1: Equilibrium data for Freundlich isotherm model

\begin{tabular}{cccc}
\hline $\boldsymbol{Q}_{e}(\mathrm{mg} / \mathbf{g})$ & $\boldsymbol{C}_{\boldsymbol{e}}(\mathrm{mg} / \mathbf{L})$ & $\boldsymbol{l n} \boldsymbol{Q}_{e}(\mathrm{mg} / \mathbf{g})$ & $\ln \boldsymbol{C}_{\boldsymbol{e}}(\mathbf{m g} / \mathbf{L})$ \\
\hline 1.9595 & 3.8103 & 0.6727 & 1.3377 \\
2.1524 & 4.1595 & 0.7666 & 1.4254 \\
2.2087 & 4.6543 & 0.7924 & 1.5378 \\
2.3175 & 4.9421 & 0.8405 & 1.5978 \\
\hline
\end{tabular}

Table 2: Equilibrium data for Langmuir isotherm model

\begin{tabular}{ccc}
\hline $\boldsymbol{Q}_{\boldsymbol{e}}(\mathbf{m g} / \mathbf{g})$ & $\boldsymbol{C}_{\boldsymbol{e}}(\mathbf{m g} / \mathbf{L})$ & $\boldsymbol{C}_{e} / \boldsymbol{Q}_{e}(\mathbf{g} / \mathbf{m g})$ \\
\hline 4.6231 & 21.76 & 4.7067 \\
4.5584 & 26.63 & 5.8421 \\
5.5645 & 34.50 & 6.2001 \\
5.4297 & 39.61 & 6.9267 \\
5.1818 & 45.6 & 8.8011 \\
\hline
\end{tabular}

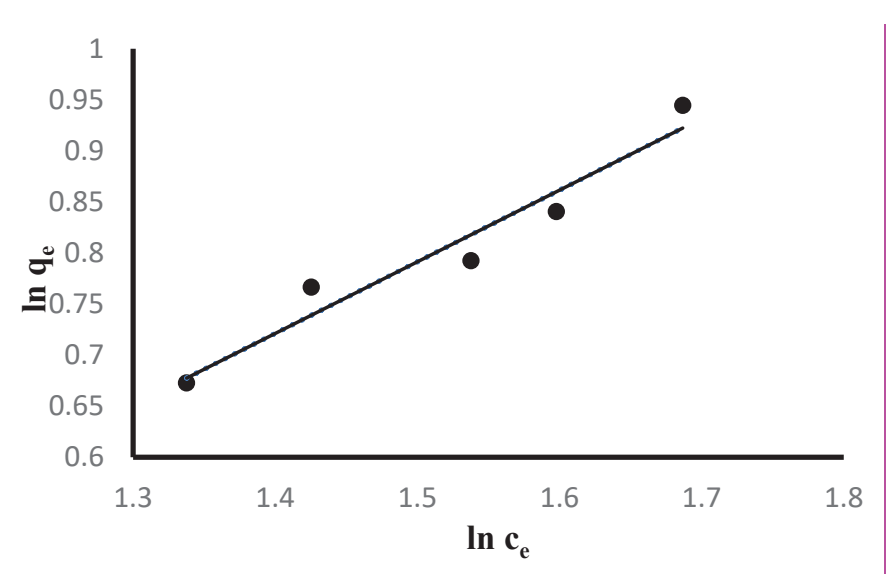

Fig. 5: Freundlich isotherm for boron removal using M. oleifera seeds.

From the plots, the estimated isotherm parameters were calculated and presented on Table 3. From the data, $R^{2}$ for Freundlich adsorption isotherm was 0.9422 whereas that of Langmuir isotherm was 0.9115 . The results showed that adsorption process evidently fitted well with the Freundlich isotherm model with high regression value. This expression predicted that the boron uptake takes place on a heterogeneous surface by monolayer sites adsorption of $M$. oleifera seeds. 


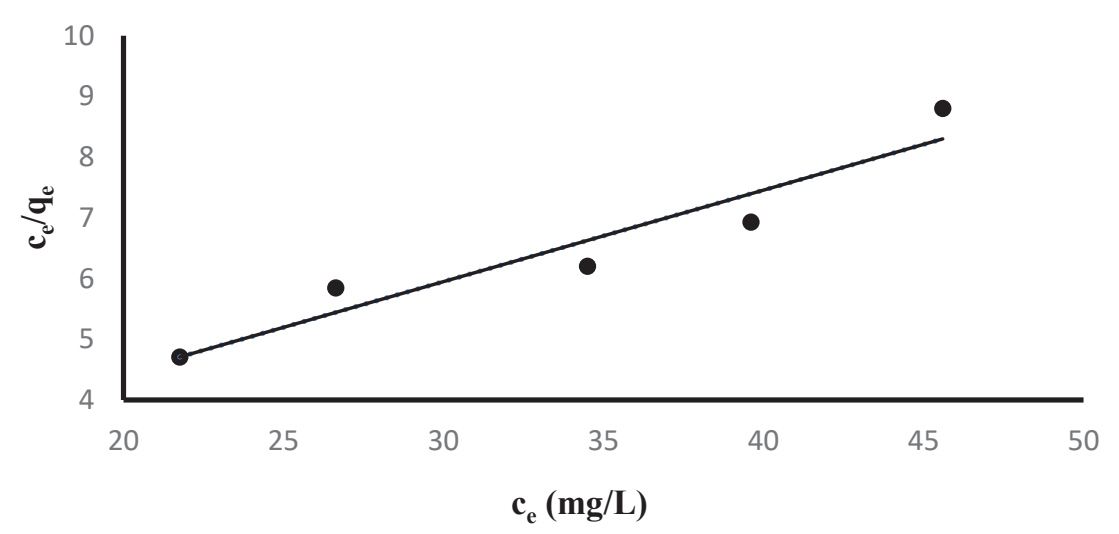

Fig. 6: Langmuir isotherm for boron removal using M. oleifera seeds.

From the plots, the estimated isotherm parameters were calculated and presented on Table 3. From the data, $R^{2}$ for Freundlich adsorption isotherm was 0.9422 whereas that of Langmuir isotherm was 0.9115 . The results showed that adsorption process evidently fitted well with the Freundlich isotherm model with high regression value. This expression predicted that the boron uptake takes place on a heterogeneous surface by monolayer sites adsorption of $M$. oleifera seeds.

Table 3 Isotherm parameters for adsorption of boron into M. oleifera seeds

\begin{tabular}{cccl}
\hline Isotherm model & \multicolumn{3}{c}{ Estimated isotherm parameter } \\
\hline Freundlich & $n$ & $K_{f}$ & $R^{2}$ \\
& 0.7014 & 1.8231 & 0.9422 \\
Langmuir & $q_{\max }\left(\frac{m g}{g}\right)$ & $b\left(\frac{L}{m g}\right)$ & $R^{2}$ \\
& 6.6357 & 0.1055 & 0.9115 \\
\hline
\end{tabular}

The standard curve equation, $y=0.0054 x+0.0363$ was used to find the final concentration of boron with $R^{2}=0.9702$ by measuring absorbance at $657 \mathrm{~nm} . y$-value is indicated by the measured absorbance value at $657 \mathrm{~nm}$ of solution after each batch experiment, whereas $x$ value is the final concentration of boron.

\subsection{Modelling by Statistical Analysis}

In this study, the model was structured by Design Expert version 6.0 .8 and created by Factorial Central Composite Design (FCCD) under Response Surface Method. The three parameters which were optimized using FCCD are $\mathrm{pH}$, contact time and dosage of adsorbent. Other parameters such as agitation speed were fixed at $200 \mathrm{rpm}$ and the experiment was conducted at room temperature. From the 20 experimental runs, the results were analysed using the analyses of variance (ANOVA) (Table 4). The highest removal efficiency of $65 \%$ was found at $\mathrm{pH} 8$, adsorbent dosage of $6000 \mathrm{mg} / \mathrm{L}$ and contact time of 60 min. Table 5 shows the ANOVA for Boron adsorption by M. oleifera seeds. 
Table 4: Results for batch adsorption experiment using M. oleifera seeds

\begin{tabular}{ccccc}
\hline Run & A: $\mathbf{p H}$ & $\begin{array}{c}\text { B: Adsorbent } \\
\text { dosage (gram) }\end{array}$ & $\begin{array}{c}\text { C: Contact time } \\
(\mathbf{m i n})\end{array}$ & $\begin{array}{c}\text { Percentage boron removal (\%) } \\
\mathbf{C i}-\boldsymbol{C} \boldsymbol{f}\end{array} \times \mathbf{1 0 0}$ \\
\hline 1 & 8 & 0.6 & 120 & 65 \\
2 & 9 & 0.4 & 180 & 35 \\
3 & 7 & 0.8 & 180 & 40 \\
4 & 7 & 0.4 & 60 & 20 \\
5 & 8 & 0.6 & 120 & 65 \\
6 & 9 & 0.8 & 60 & 45 \\
7 & 8 & 0.6 & 120 & 65 \\
8 & 7 & 0.4 & 180 & 30 \\
9 & 9 & 0.4 & 60 & 30 \\
10 & 7 & 0.8 & 60 & 45 \\
11 & 9 & 0.8 & 180 & 50 \\
12 & 8 & 0.6 & 120 & 65 \\
13 & 8 & 0.8 & 120 & 58 \\
14 & 8 & 0.6 & 60 & 40 \\
15 & 8 & 0.6 & 120 & 65 \\
16 & 8 & 0.4 & 120 & 30 \\
17 & 9 & 0.6 & 120 & 59 \\
18 & 8 & 0.6 & 120 & 65 \\
19 & 8 & 0.6 & 180 & 53 \\
20 & 7 & 0.6 & 120 & 30 \\
\hline
\end{tabular}

Table 5: ANOVA analysis for the adsorption using M. oleifera seeds

\begin{tabular}{ccccccc}
\hline Source & $\begin{array}{c}\text { Sum of } \\
\text { square }\end{array}$ & DF & $\begin{array}{c}\text { Mean } \\
\text { square }\end{array}$ & F value & Prob $>$ F & \\
\hline Model & 2744.60 & 9 & 304.96 & 4.00 & 0.0319 & significant \\
$A$ & 291.60 & 1 & 291.60 & 3.82 & 0.0863 & \\
$B$ & 864.90 & 1 & 864.90 & 11.34 & 0.0098 & \\
$C$ & 78.40 & 1 & 78.40 & 1.03 & 0.3404 & \\
$A^{2}$ & 175.60 & 1 & 175.60 & 2.30 & 0.1677 & \\
$B^{2}$ & 197.98 & 1 & 197.98 & 2.59 & 0.1459 & \\
$C^{2}$ & 99.49 & 1 & 99.49 & 1.30 & 0.2865 & \\
$A B$ & 3.13 & 1 & 3.13 & 0.041 & 0.8447 & \\
$A C$ & 3.13 & 1 & 3.13 & 0.041 & 0.8447 & \\
$B C$ & 28.13 & 1 & 28.13 & 0.37 & 0.5606 & \\
Residual & 610.40 & 8 & 76.30 & & & not \\
Lack of Fit & 534.40 & 5 & 106.88 & 4.22 & 0.1328 & significant \\
& & & & & & \\
Pure Error & 76.00 & 3 & 25.33 & & & \\
Cor Total & 3534.55 & 19 & & & &
\end{tabular}

Based on the analysis of the model in Table 5 above, the Model F-value of 4.00 implies the model is significant. There is only a 3.19\% chance that a "Model F-Value" this large could occur due to noise. Values of "Prob $>$ F" less than 0.0500 indicate the model are significant. In this case B is a significant model term. Values greater than 0.1000 indicate the model terms are not significant. The "Lack of Fit F-value" of 4.22 implies the Lack of Fit is not significant relative to the pure error. There is a $13.28 \%$ chance that a "Lack of Fit F-value" this large could occur due to noise. Non-significant lack of fit is good as it shows that the model is in a good fit. 
Table 6 Overall analysis of the model

\begin{tabular}{cccc}
\hline Std. Dev. & $\mathbf{8 . 7 3}$ & R-Squared & $\mathbf{0 . 8 1 8 1}$ \\
\hline Mean & 46.15 & Adj R-Squared & 0.6134 \\
C.V. & 18.93 & Pred R-Squared & -1.1132 \\
PRESS & 7089.85 & Adeq Precision & 6.450 \\
\hline
\end{tabular}

A negative "Pred R-Squared" implies that the overall mean is a better predictor of the response than the current model. "Adeq Precision" measures the signal to noise ratio. A ratio greater than 4 is desirable. The ratio of 6.450 indicates an adequate signal. This model can be used to navigate the design space. The coefficient of variation $\%(\mathrm{CV} \%)$ which can be used to measure the reliability and precision of the experiment was found to be 18.93 which is quite reliable. The higher the value of $\mathrm{CV} \%$, the less reliable is the experiment. The $\mathrm{CV}$ value is a measure of residual variation of the data relative to the size of the mean. The value of predicted residual sum of squares (PRESS) is found to be 7089.85. It is a measurement of how fit of each point in the design. The smaller the PRESS value, the better the model fits the data points.

According to the model equation generated by Design Expert 6.0 software, the 3D plots were plotted to investigate the interaction between variables. The 3D plots were generated by plotting the response (boron percentage removal) on the Z-axis against any two independent variables (Fig. 6). These plots hold a single constant variable at its centre, while the other two variables were varied in the range of experimental values. From the 3D plot indicated that it is possible to increase the percentage removal of boron further when the contact time, $\mathrm{pH}$ value and adsorbent dosage increased.

Previous studies on optimization of boron removal that adsorbed by different adsorbent are compared with the $M$. oleifera adsorption in terms of $\mathrm{pH}$ and adsorption capacity. The optimum $\mathrm{pH}$ value for $M$. oleifera was in agreement with other adsorbents such as rice husk, date seed ash, chitosan and magnesite-bentonite clay where the values were in the range of $\mathrm{pH} 7$ to 10 which was in an alkaline environment [27-30]. Meanwhile, M. oleifera presented higher adsorption capacity than chitosan and magnesite-bentonite clay [27,30].

\section{CONCLUSION}

In conclusion, the results indicated that the highest percentage of boron removal was achieved up to $65 \%$ from Table 4 at optimum values of $\mathrm{pH} 8,120$ min of contact time and $6000 \mathrm{mg} / \mathrm{L}$ of adsorbent dosage. The decrease in removal rate after the optimum time of 120 min was probably due to continuous aggregation at the adsorption sites. The effect of $\mathrm{pH}$ variation with boron removal was associated with weak electrostatic forces between the adsorbate and the adsorbents, which manifested much at $\mathrm{pH}$ greater than 8 . It was shown that boron removal increases with increase in adsorbent dosage with climax at $6000 \mathrm{mg} / \mathrm{L}$. However, removal plummeted beyond this range due to decrease in the contact surface area available. The adsorption studies showed that the expressions were well fitted to Freundlich isotherm compared to Langmuir isotherm model. Statistical analysis modelling showed that the model was significant and thus confirm the effect of the combination parameters and conditions for the removal of boron from the solution. 
DESIGN-EXPERT Plot

Percentage removal of boron

$X=C$ : Contact time

Actual Factor

A: $\mathrm{pH}=8.00$

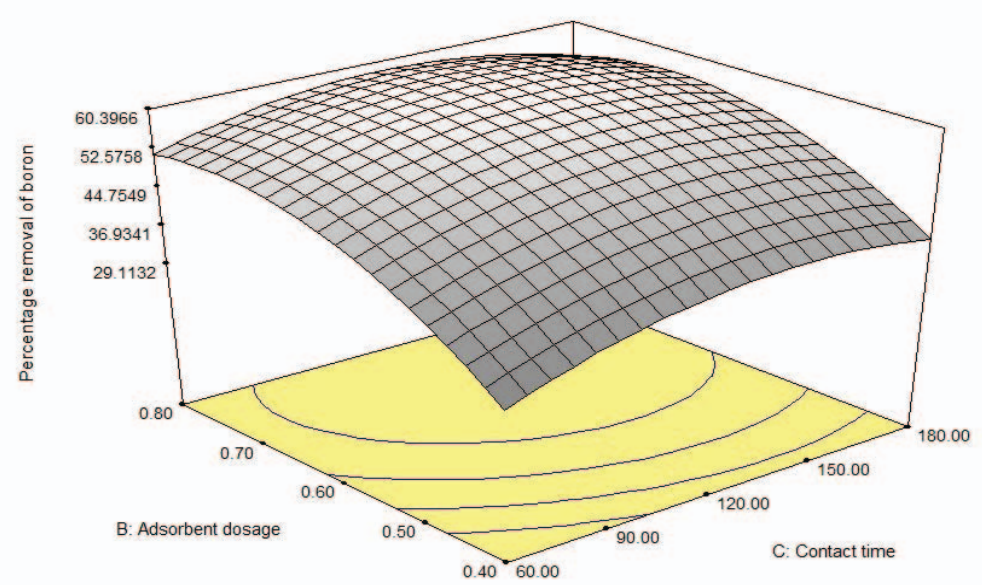

a)

DESIGN-EXPERT Plot

Percentage removal of boron $\mathrm{X}=\mathrm{A}: \mathrm{pH}$
$\mathrm{Y}=\mathrm{C} \cdot \mathrm{Contact}$ time

$\mathrm{Y}=\mathrm{C}:$ Contact

Actual Factor
B. Adsorbent dosage $=0.60$

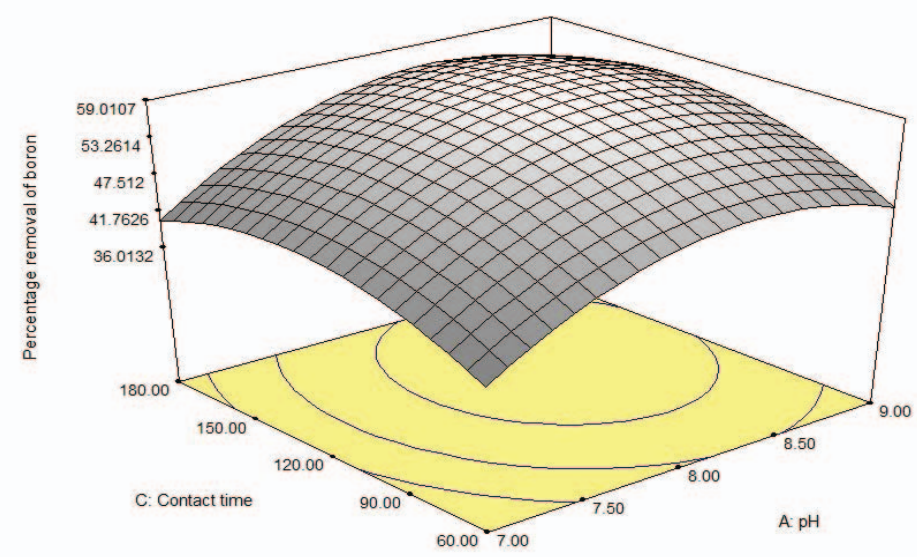

b)

DESIGN-EXPERT Plot

Percentage removal of boron $X=A: p H$
$Y=B$ : Adsorbent dosage

Actual Factor

C: Contact time $=120.00$

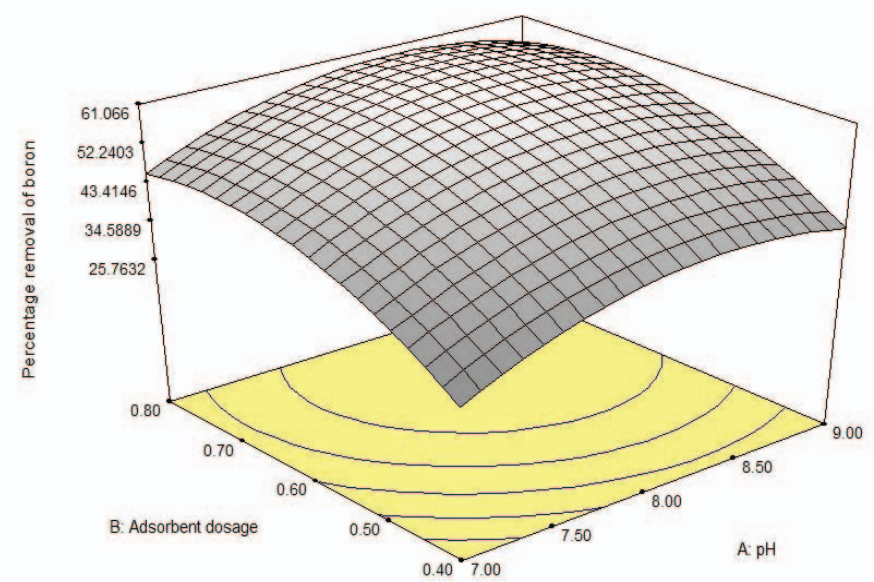

c)

Fig. 6: (a) 3D plot for percentage removal of boron as a function of contact time and adsorbent dosage; (b) 3D plot for percentage removal of boron as a function of $\mathrm{pH}$ and adsorbent dosage; (c) 3D plot for percentage removal of boron as a function $\mathrm{pH}$ and contact time. 


\section{ACKNOWLEDGEMENT}

The authors express their thanks to Ministry of Higher Education (MOHE) Malaysia for granting a Fundamental Research Grant Scheme (FRGS), project no. FRGS-19-194-0803 for the financial support for this work.

\section{REFERENCES}

[1] Princi MP, Lupini A, Araniti F, Longo C, Mauceri A, Sunseri F, Abenavoli MR (2016). Boron Toxicity and Tolerance in Plants: Recent Advances and Future Perspectives. In Plant Metal Interaction, Edited by Parvaiz A. Elsevier; pp 115-147.

[2] Zhang J, Cai Y, Liu, K. (2019). Extremely Effective Boron Removal from Water by Stable Metal Organic Framework ZIF-67. Industrial \& Engineering Chemistry Research, 58: 4199_ 4207. doi.org/10.1021/acs.iecr.8b05656

[3] Khaliq H, Juming Z, Ke-Mei P (2018). The Physiological Role of Boron on Health. Biological Trace Element Research, 186: 31-51. doi:10.1007/s12011-018-1284-3

[4] Guan Z, Lv J, Bai P, Guo X. (2016). Boron removal from aqueous solutions by adsorption A review. Desalination, 383: 29-37. doi.org/10.1016/j.desal.2015.12.026

[5] Guidelines for drinking-water quality, 2nd ed. Addendum to Vol. 2. Health criteria and other supporting information. (1998) World Health Organization, Geneva.

[6] Kabu M, Akosman M S. (2013). Biological Effects of Boron. Reviews of Environmental Contamination and Toxicology, Edited by Whitacre D M. Springer; pp 57-75. doi:10.1007/978-1-4614-6470-9 2

[7] Tu K L, Nghiem L D, Chivas A $\overline{\mathrm{R}}$ (2010). Boron removal by reverse osmosis membranes in seawater desalination applications. Sep. Purif. Technol, 75: 87-101. doi:10.1016/j.seppur.2010.07.021

[8] Kim BC, Hung P V X, Moon S H (2010). Boron removal from seawater by combined system of seawater reverse osmosis membranes and ion exchange process: a pilot-scale study. Desalination and Water Treatment, 15: 178-182. doi:10.5004/dwt.2010.1683

[9] Kabay N, Bryjak M (2015). Boron Removal from Seawater Using Reverse Osmosis Integrated Processes. In Boron Separation Processes, Elsevier 219-235. doi:10.1016/b9780-444-63454-2.00009-5

[10] Biniaz P, Torabi Ardekani N, Makarem M, Rahimpour M (2019). Water and Wastewater Treatment Systems by Novel Integrated Membrane Distillation (MD). ChemEngineering, 3: 1-36. doi:10.3390/chemengineering3010008

[11] Tagliabue M, Reverberi A P, Bagatin R (2014). Boron removal from water: needs, challenges and perspectives. Journal of Cleaner Production, 77: 5664. doi:10.1016/j.jclepro.2013.11.040

[12] Ozturk N, Kavak D (2005). Adsorption of boron from aqueous solutions using fly ash: Batch and column studies. Journal of Hazardous Materials, 127: 8188. doi:10.1016/j.jhazmat.2005.06.026

[13] Yüksel S, Yürüm Y (2009). Removal of Boron from Aqueous Solutions by Adsorption Using Fly Ash, Zeolite, and Demineralized Lignite. Separation Science and Technology, 45: 105-115. doi:10.1080/01496390903256042

[14] Montalvo-Andia J P, Yokoyama L, Cesar Teixeira L A (2018). Study of the Equilibrium, Kinetics, and Thermodynamics of Boron Removal from Waters with Commercial Magnesium Oxide. International Journal of Chemical Engineering, 2018: 110. doi:10.1155/2018/6568548.

[15] Wibowo E, Rokhmat M, Abdullah M (2017). Reduction of seawater salinity by natural zeolite (Clinoptilolite): Adsorption isotherms, thermodynamics and kinetics. Desalination, 409:146-156. doi.org/10.31436/iiumej.v21i1.1254

[16] Anjorin T B, Ikokoh P, Okolo S (2010). Mineral composition of Moringa oleifera leaves, pods and seeds from two regions in Abuja, Nigeria. Int. J. Agric. Biol. 12: 431- 434. 
[17] Kansal S K, Kumari A (2014). Potential of M. oleifera for the treatment of water and wastewater. Chem Rev.114: 4993-5010. doi: 10.1021/cr400093w

[18] Reddy D H K, Harinatha Y, Seshaiaha K, Reddy A V R (2010). Biosorption of Pb(II) from aqueous solutions using chemically modified Moringa oleifera tree leaves. Chem. Eng. J. 162: 626-634.

[19] Camacho F P, Sousa V S, Bergamasco R, Teixeira M R (2017). The use of Moringa oleifera as a natural coagulant in surface water treatment. Chem. Eng J., 313: 226-237.

[20] Reck I M, Paixão R M, Bergamasco R, Vieira M F, Vieira A M S (2018). Removal of tartrazine from aqueous solutions using adsorbents based on activated carbon and Moringa oleifera seeds. J. Clean Prod., 171: 85-97.

[21] Zarei A R, Nobakht S, Zaree M A (2012). A New Separation and Preconcentration System Based on Dispersive Liquid-Liquid Microextraction for Spectrophotometric Determination of Trace Amounts of Boron in Water Samples, JTAFD, 1: 1-13.

[22] Ahmad M M, Azoddein A A M, Zahari M A K M, Seman M N bin A, Saedi M J, Olalere O A, Alara O R (2019). Optimization of Process Parameters in Mixed Sulfide Oxidation Bacterial Culture Using Response Surface Methodology as a Tool. Journal of King Saud University, 31: 836 - 843. doi.org/10.1016/j.jksus.2017.11.001

[23] Glass B, Using S, Techniques M B, Shimada K, Kobayashi M, Tominaga G. (2016). Adsorption Study on Moringa Oleifera Seeds and Musa Cavendish as Natural Water Purification Agents for Removal of Lead, Nickel and Cadmium from Drinking Water. IOP Conf. Series: Materials Science and Engineering 136: 1-10. 012044 doi:10.1088/1757899X/136/1/012044

[24] Mahvi A H, Ghanbarian M, Nasseri S, Khairi A (2009). Mineralization and discoloration of textile wastewater by $\mathrm{TiO}_{2}$ nanoparticles. Desalination, 239: 309-316. doi:10.1016/j.desal.2008.04.002

[25] Al Haddabi M, Ahmed M, Al Jebri Z, Vuthaluru H, Znad H, Al Kindi M (2016). Boron removal from seawater using date palm (Phoenix dactylifera) seed ash. Desalination and Water Treatment, 57: 5130-5137. https://doi.org/10.1080/19443994.2014.1000385

[26] Mohammed S J, Nur Syahirah Z, Moussa M A, Mohammed N, Mani M A (2018), Optimization of Process Parameters for Boron Adsorption from Sea Water Using Moringa oleifera Seeds, 5th International Conference on Biotechnology Engineering ICBioE, Kuala Lumpur, Malaysia 19 - 20.

[27] Copello G J, Villanueva M E, González J A, López Egües S, Diaz L E (2014). TEOS as an improved alternative for chitosan beads cross-linking: A comparative adsorption study. Journal of Applied Polymer Science, 131: 1-8. doi.org/10.1002/app.41005

[28] Guan Z, Lv J, Bai P, Guo X (2016). Boron removal from aqueous solutions by adsorption A review. Desalination, 383: 29-37. doi.org/10.1016/j.desal.2015.12.026

[29] Al Haddabi M, Ahmed M, Al Jebri Z, Vuthaluru H, Znad H, Al Kindi M (2016). Boron removal from seawater using date palm (Phoenix dactylifera) seed ash. Desalination and Water Treatment, 57: 5130 -5137. doi.org/10.1080/19443994.2014.1000385

[30] Masindi V, Gitari M W, Tutu H, Debeer M (2016). Removal of boron from aqueous solution using magnesite and bentonite clay composite. Desalination and Water Treatment, 57: 8754-8764. doi.org/10.1080/19443994.2015.1025849 